\title{
Leadership Style, Government Regulations and Sustainability of Sacco Societies in Kenya. A Case Study of Harambee Sacco
}

\author{
Thiong'o Samuel Mungai \& Nyaga G. Juster \\ Tutorial Fellow \\ The Management University of Africa \\ Nairobi, Kenya.
}

\begin{abstract}
The study investigated the factors affecting sustainability of Sacco societies in Kenya with Harambee Sacco as the case study. The objectives of the study were to establish the effects of leadership style and government regulation on Sacco sustainability. The study adopted descriptive research design and used stratified random sampling procedure to select the sample population. The researcher targeted 140 respondents from Sacco membership where a sample size of 50\% selected. The study found that both leadership style and government regulation affect Sacco society's sustainability in Kenya. The study recommends that Saccos should adopt the best leadership style to give a good direction towards sustainability goal. In addition, the study recommends that Saccos should ensure extensive research is done on how to conform to the government regulation and the government should create favorable regulation for Saccos in Kenya.
\end{abstract}

Keywords: Sustainability, Sacco Societies, leadership style, government regulation.

\section{Introduction}

Savings and credit cooperatives (SACCOs) are association of persons who have pulled together with common goals aimed at improving their livelihood economically. They are an important part of the financial sector in Kenya providing savings, credit and investment services to a large portion of the population (Lari,2009). On the African continent, Kenya has one of the most vibrant co-operative environments, with more than 10,000 registered co-operatives, of which about 4,000 are SACCOs. In total, co-operatives make up about 43\% of Kenya's GDP (UN, 2009).

In Kenya, cooperative movement dates back to 1931 when the first ordinance to regularize the operation of the cooperatives in the country was enacted. The following decade witnessed increased intervention in the sector with the eventual enactment of the Cooperative Ordinance Act of 1945, the predecessor of the current cooperative Societies Act Cap 490 of the law of Kenya as amended in 1977. SACCOs are registered and regulated under the Cooperative Societies Act. For registration the Act requires a primary society to consist of at least ten persons. The vast number of SACCOs in Kenya has been formed over the years with some being created as early as 1968. These SACCOs target a specific segment of population with similar orientation. These are mainly low income earners and the society has the objective of uplifting their financial status through investment. SACCOs with their diverse products and services, have given a new meaning to the financial sector in Kenya. Their most popular service is that of saving, which has evidently been the surest way to break the vicious cycle of poverty and is fundamental to sustainable economic development (Kuria, 2011).

Globally, co-operatives act as a source of shelter, employment, representation, food and credit. The United Nations (Smith, 2014) estimates that co-operatives impact the livelihoods of three billion people globally. Additionally, its statistics show that at least one hundred million people are employed by co-operatives and one billion people are members of them. Co-operatives make up between 3\% and 3.5\% of global GDP. In countries like Kenya and New Zealand, co-operatives contribute significantly to the countries' economies, making up $45 \%$ and $22 \%$ of GDP respectively (UN, 2009).

In Europe, co-operative banks represent 850,000 employees and 56 million members, and have an average market share of $20 \%$ in the financial industry. These co-operatives run almost 4,000 locally operating financial firms and 71,000 outlets, and serve more than 215 million customers, who are mainly consumers, small and medium enterprises and communities (Smith, 2014). Harambee Sacco is one of the vibrant Saccos societies in Kenya. The Sacco was set up by a handful of small income earners and struggling subordinate staff at the Office of the President (OP), in 1970. 
Harambee Sacco nowdays are a multi-billion shilling institution, with thousands of members and an expansive countrywide network that few financial institutions in Kenya can match. With a net asset base of about Ksh. 17.6 billion, Harambee Sacco, is feted amongst the top ten biggest membership base Saccos in Kenya; boasting of over 86, 934 members across that country(Mutua,2009)

From a single unit at the office of the President, Harambee Sacco has now been devolved into 175 delegate or electoral branches across Kenya, serving its members in the remotest of locations in that country. Indeed, Harambee Sacco continues to enjoy a customer penetration level that goes way down into the minute administrative level in Kenya with chiefs and sub-chiefs in the locations and sub-locations being members of Harambee Sacco (Mutua,2009). This Sacco was chosen as a case study because it represents one of the vibrant and active Sacco that can represent the Kenya society.

Kimando, Kihoro and Njogu (2012), define sustainability in general as to the ability of a given activity to continue into the future within the likely resources of an organization. In financial terms, sustainability refers to an organization's ability to service all of its expenses through its generated income. Sarma (2011) collaborates this definition by adding that microfinance institutions can be said to be sustainable when their operating income from issuing loans is sufficient to cover all operating costs. In the case of SACCOs, the definition is extended to cover the ability to continue operations with savings and credit services to the members into foreseen future.

\section{Statement of the Problem}

Sustainability is the degree of satisfaction provided by the goods and services of a company as measured by the number of repeat customers. It is also the quality or state of being satisfied or contentment.

Extensive research has been carried out on financial challenges facing SACCOs in Kenya. For example, Gunga (2009) lists several challenges facing SACCOs such as cash flow problems, loan backlog, delayed refunds of members deposits, competition from banks, poor members loyalty, liquidity and cash flow problems, short vs long term lending. According to Oliver (2009) there are constraints facing development of SACCOs as lack of appropriated and adequate managerial skills and knowledge with the good strategic, business, succession plans and adequate organizational set-up and transparent operational system.

The sustainability of SACCOs in Kenya is a major issue in the sector, studies indicate that upto51\%failurerateofSACCOsinKenya have been identified(Gok,2011). SACCOsin Kenya are unique in that employees and members enjoy many benefits including highly concessional and discounted internal employer/member loans. They also compete for the same savings with the commercial banks and mobile money services which happen to be service providers of the SACCO members. This poses the question, "Does leadership style and government regulations affect sustainability of SACCO societies in Kenya?

\section{Objectives of the Study}

a) To determine the effect of leadership Style on the sustainability of Sacco societies in Kenya.

b) To investigate the effect of government regulation on the sustainability of Sacco societies in Kenya.

\section{Literature Review}

\subsection{Theories}

\subsubsection{Institutional Theory}

According to Doug and Scott (2004), Institutional theory attends to the deeper and more resilient aspects of social structure. It considers the processes by which structures, including schemas; rules, norms, and routines, become established as authoritative guidelines for social behavior. It inquiries into how these elements are created, diffused, adopted, and adapted over space and time; and how they fall into decline and disuse. Although the ostensible subject is stability and order in social life, students of institutions must perforce attend not just to consensus and conformity but to conflict and change in social structures.

The basic concepts and premises of the institutional theory approach provide useful guidelines for analyzing organization-environment relationships with an emphasis on the social rules, expectations, norms, and values as the sources of pressure on organizations. This theory is built on the concept of legitimacy rather than efficiency or effectiveness as the primary organizational goal (Doug and Scott, 2004). Researchers such as Meyer and Rowan (1991),DiMaggio and Powell (1983)are someoftheinstitutionaltheoristswhoassertthattheinstitutionalenvironment can strongly influence the development of for malstructures in an organization, often more profoundly than market pressures. Innovative structures that improve technical efficiency nearly-adopting organization sarelegitimizedin the environment. 
This the oryisrelevant to the study asitexplain show in situational environment; that is the desire to explore organization defines the sustain able management practices of an organization and how such practices affects performance fan institution. This theory addresses two independent variables of leadership style and government regulation.

\subsubsection{Modern portfolio theory}

In investment, modern portfolio theory management is a critical theory it tries to look for the most efficient combinations of assets to maximize portfolio expected returns for given level of risk. Alternatively, minimize risk forgiven level of expected return. Portfolio theory is presented in a mathematical formulation and clearly gives the idea of diversifying the assets investment combination with a purpose of selecting those assets that will collectively lower the risk than any single asset. In the theory, it clearly identifies this combinationismadepossiblewhentheindividualassetsreturnandmovement is opposite direction. An investor there foreneeds to study the value movement of the intended asset investment and find out which assets have an opposite movement. However, risk diversification lowers the level of risk even if the assets' returns are not negatively or positively correlated (Omisore et al., 2012).

Risk is defined as the standard deviation of return, i.e., to what extend is the actual return deviating from the expected return. Therefore, portfolio being a combination of assets, the model becomes a weighted combination of these assets' returns. When different assets are combined and whose returns are not perfectly positively correlated, then portfolio theory leads to reduction of the total variance of such asset combination returns over a given period of investment.Thereturniscalculatedbygettingthechangeinvalueoftheassets plus any distribution received during a given period over which the assets are held and expressed as a fraction of the initial outlay. From this theory, it is evident that the level of risk in a portfolio depends on risk of each asset, proportion of resources allocated on each asset and the interrelationship between the assets making up the portfolio. The major assumption sin portfolio theory in managing risk are that the investors are rational and the market is efficient and perfect (Chijoriga,2007).

This theory addresses the sustainability variable. The modern portfolio theory demonstrates that organizations manage their businesses on a portfolio basis. Withassumptionsthatinvestorsarehomogenousandriskaverse, theyhave to be motivated to invest, they need a rate of return that will compensate them for taking on the risk at the end of period of holding given asset(s). It is therefore important for SACCOs to deploy prudent sustainability management practices in ordertoinstillcontrolwithinthevariousportfolioswithatargetofmaximizing returns on each investment.

\subsection{Empirical Studies}

\subsection{Leadership Style and Sustainability}

Leadership style is the manner and approach of providing direction, implementing procedures and plans and motivating people. For sustainability leadership style is almost as variable as unique and is based on the strengths, weaknesses, needs and beliefs. The bottom line is that an organization is made up of people who have certain beliefs. Excellent in leadership behaviour begins with understanding these attributes of the followers. For profit making organizations like Saccos, the needs of a leadership skills to attain the desired sustainability cannot be ruled out (Kuria, 2011). A constructive culture is one where there is a sense of achievement, challenge, growth, encouragement and humanistic relationships. The organizations with constructive culture have a higher profit margin and sustainability potential.

The study performed by registered Saccos in US to trace the effects of manager leadership characteristics on Saccos sustainability and profitability concluded that the leadership style in an organization contributes greatly to sustainable level. Effects of manager characteristic were traced to sustainability through work characteristics such as job stress, job satisfaction, commitment and intent to stay. Manager consideration of staff and retained employee intent to remain directly affected Sacco sustainability (Kimando et al., 2011).

Dawson (2009) stated that a manager leadership can measurably increase sustainability in Saccos through employee performance and retention. Studies show that when the leadership style in an organization is improved there is much satisfaction by employees, regardless of occupation. The level or demographic group consistently found that the greatest source of stress and demotivation at work is a negative relationship with the manager (Dawson,2013). However, a positive relationship can have an enormous impact on reducing work related stress and increasing motivation and organizational commitment leading to sustainability and high profits by a Sacco.

Dawson (2013) thought that the leadership style means a kind of method and capability aimed at realizing organizational targets and further affect all organizational activities. A Sacco requires a leadership that can deliver the expectations of the members. 
Leadership is the capacity to establish direction, to influence, align others towards a common goal, motivating, committing them to action and making them responsible for their sustainable performance. Leadership is needed in order to guide the organizational effort towards achievement of its goals. It seeks to give sustainable direction, without which the organization tends to be a muddle of men end machines. It persuades others to seek defined goals enthusiastically, motivates employees guides them towards the goals and thus sustaining the Sacco.

Leadership in Sacco sustainability takes into account public policy, national values and ethics. It covers systems by which the individual corporation regulates itself for competitiveness and sustainability of the sector through practices and procedures for supervising, monitoring, regulating and controlling its affairs. For Saccos to be sustainable ,efficient and productive, they must apply good governance practices that seek to ensure that the power of the organization is used in manner that ensures effectiveness, efficient, fairness, transparency, discipline, accountability, responsibility, independence and social responsibility (Kimando et al.,2011).

According to Dawson (2013), good leadership style in any organization sustainability, involve better dissemination of information concerning all departments and coordinating their operating methods and practice to maintain basic uniformity, foster education, training of members, officials and employees of any organization. It fosters and promotes the organization's growth and is capable of promoting the investment and general welfare of their members in accordance with principles to be able to maintain the general Sacco's profitability. Good leadership helps regulate mechanisms and performance in the work places as well as motivation of the employees which creates sustainability drive and increased market share.

According to Dawson (2013), for any Sacco to improve its sustainability, it must develop trusting relationship with those whom they seek to lead. Organizations are increasingly searching for leaders who can exhibit transformational leadership qualities. They want leaders with visions and charisma to carry out those visions. True leadership effectiveness may be as result of exhibiting the right behavior at the right time. Leaders envision the future; they inspire employees. In the Sacco, the leaders must instill values and have the ability to use power effectively and in a responsible manner. They must have the ability to comprehend that people have different motivation forces at different times and in different situations which keep the employees in the organization and which bring about good returns.

Hence, lack of good leadership affects the sustainable performance of the organizations in relation to achieve profitability level. This is a problem which needs to be taken into consideration before it goes out of hand.

\subsection{Government Regulation and Sustainability}

SACCOs in Kenya are required to adhere to regulations set out by the Sacco Societies Regulatory Authority (SASRA). The board of SASRA is constituted by; the Commissioner of cooperatives, the Central Bank Governor who represents treasury and the Ministry of finance, and four members of the public. The government sets regulations which should be followed by any Sacco concerning the operation of financial services through the ministries of Finance, Trade and Industrialization in an effort to reform SACCOs and ensures that the public has confidence in the SACCOs sector and thus spur Kenya's economic growth through the mobilization of domestic savings (KUSCCO, 2003). It is concerned with the guidelines of the company's welfare to prevent unethical operation of organization. The importance of the Sacco sub-sector in Kenya led the Government to enact the Sacco Act 2008 and the Sacco Societies Regulations (KUSCCO, 2009). With the intention of protecting the interest of SACCO members and improving the confidence of the public in SACCOs, the Act created the SASRA whose mandate entails licensing, regulating and supervising Sacco societies engaged in deposit taking business (KUSCCO,2009).

Regulation may also refer to a rule or guideline designed to control the conduct of those it applies, regulations are official rules and have to be followed. According to Government of Kenya (2011), a regulation or a policy is a set of interrelated decisions taken by a political actor or a group of actors concerning the selection of goals and the means of achieving them within a specified period and context.

According to Cary (2011), well-conceived financial regulation can encourage competition and ensure fair markets for goods and services. Thus, government develops public policy to guide commerce, a set of laws and regulations that limit business for the good of society as a whole. Sacco Legislations affecting business around the world has increased steady over the years, for instance, product, safety, consumer privacy, pricing, environmental protection, competition and fair trade practices. The Sacco rules are subsidiary legislation made by the Minister who derives powers to make rules from Section A3 of the Finance Act in Kenya.

The government through the Ministry of Finance GOK,2011) sets rules of conducts and enforces them to control and regulate the conduct of all financial institutions in Kenya through the Central bank in Kenya, for example, Finance Act, is an Act of Parliament that makes provision for the licensing, regulation, supervision of non-deposit taking financial institutions, establish the finance regulatory authority and related purposes. 
The Finance Act 2010 passed relates to branchless banking which amends the Banking Act and micro finance Act to allow for use of agents. Another regulation relates to proceeds of crime and money laundering Bill of 2009. The Growth and sustainability of Sacco involves a permanent increase in the size, scale, and complexity of microfinance activities in the country. Growth in the banking industry is desirable to reduce poverty and enables institutions to reduce average costs and losses. Managing and planning growth will require the deliberate actions and strategies designed by policy makers and industry leaders.

Many policy issues are addressed but two are recognized as playing a large role for sustainability: an appropriate regulatory environment and strong property rights. Generally, improvements in the policy environment of a country contribute to the overall performance of its institutions. Competent external regulation and supervision can identify, avoid and resolve many common problems experienced for an organization to achieve its sustainability and profitability. In many countries, Sacco societies need a supportive regulation framework to be sustainable. A wellfunctioning and efficient legal system is a very important sustainability factor needed to enhance the performance of Saccos.

Saccos are some of the organizations which bring economic growth through improvement of economy in terms of finance. They are unique in that, out of their services and daily contribution towards economic development. The government through the Ministries of Finance or co-operatives issues policies which guide their operation. Their policies are reviewed periodically to be in line with changing economic conditions to help in sustainability of the enterprises. Changes in political environment often lead to changes in legal environment and in the way existing laws are enforced. It is hard for organizations to know all the relevant laws but it is of essence that they do so because the legal environment sets basic rules of how business can operate in the society. The legal environment may sincerely limit some choices in changes in laws and how they are interpreted regarding the sustainability of companies in their period of operation (Kirkpatrick, 2001).

\section{Research Design and Methodology}

The descriptive research design was used to collect data from the respondents. The study adopted a case study research design which is a form of descriptive research since this allowed the researcher to carry the study without affecting the flow of work.

The target population of this study was the management and membership of the Sacco, Nairobi branch which consisted of 140 members. The sampling technique used was stratified random sampling. The technique was best suited for this research because the population was heterogeneous. The study used 50\% of the target population to arrive at 70 number of respondents as its sample size.

Primary data collection was done by the administration of questionnaires to the respondents. Reliability and Validity of the questionnaire was achieved by pre-testing the instrument to identify and change any ambiguous, awkward, or offensive questions and technique as emphasized by Cooper and Schindler (2003). The respondents who participated in the pilot study were not included in the final data analysis. The data was analyzed using both qualitative and quantitative techniques. The results were then presented in form tables and charts to enable easy understanding and interpretation of the information.

Multiple linear regression models were used to assess whether sustainability of Saccos is a function of the variables indicated on the specific objectives.

Where:

$\mathrm{Y}=\alpha+\beta_{1} \mathrm{X}_{1}+\beta_{2} \mathrm{X}_{2}+\mathrm{e}$ where;

$\mathrm{Y}=$ Sustainability of Sacco societies, $\alpha=$ Autonomous factors, $\mathrm{X}_{1}=$ Leadership style,

$\mathrm{X}_{2}=$ Government regulations, $\beta$ represents the beta coefficients of the independent variables, $\mathrm{e}=$ Error term

\section{Findings and Discussions}

The study collected a total of 62 questionnaires out of the 70 questionnaires distributed to the Sacco. This represents a response rate of $89 \%$. According to Mugenda and Mugenda (2003) a response rate of above $50 \%$ is adequate for study analysis, therefore $89 \%$ was good and adequate for data analysis.

\section{1leadership Style}

From the study done to investigate how leadership style affect sustainability of Sacco's, $86 \%$ of the respondents said that leadership can impact the sustainability while $14 \%$ of the respondents indicated that leadership style does not affect. The researcher found that leadership style is vital in improving Sacco firms as it affects the way employees are motivated towards achieving a stated goal and on how policies in Sacco's are communicated. 
If a Sacco can have the expected leadership style then it is likely to have a substantial growth in meeting its financials needs and having high profits margin.

\subsection{Government Regulation}

From the study on how Government Regulation affects sustainability of Sacco's, $85 \%$ of the respondents said that it affects the sustainability level while $15 \%$ of the respondents indicated that government regulation has no influence. This shows that the Government regulation can affect the growth of Sacco societies towards their sustainability and they should conform to the government rules of conduct which controls and regulates the financial sector, through the Ministry of co-operatives.

\subsection{Correlation Analysis}

A Pearson correlation was run to establish how the variables were related to each other. In reference to table 7.1, the correlation matrix indicates correlation was weak between government regulation and leadership style though positive.

The sustainability of Saccos was highly correlated to leadership style (.943) and government regulation (.856). The correlation matrix reaffirms the findings in the descriptive analysis that leadership style and government regulation are critical for the sustainability of Sacco societies.

Table 7.1: Correlation Analysis

\begin{tabular}{|l|l|l|l|}
\hline & $\begin{array}{l}\text { Government } \\
\text { Regulation }\end{array}$ & Leadership Style & Sustainability of Saccos \\
\hline Government Regulation & 1 & 1 & \\
\hline $\begin{array}{l}\text { Leadership } \\
\text { Style }\end{array}$ & 0.308 & 0.943 & 1 \\
\hline $\begin{array}{l}\text { Sustainability } \\
\text { of Saccos }\end{array}$ & 0.856 & 0.3 & \\
\hline
\end{tabular}

Correlation is significant at the 0.05 level (1-tailed).

Source: Author (2018)

\subsection{Regression Analysis}

Multiple linear regression models were used to assess whether sustainability of Saccos is a function of the variables indicated on the specific objectives.

Where:

$Y=\alpha+\beta_{1} X_{1}+\beta_{2} X_{2}+e$ where;

$\mathrm{Y}=$ Sustainability of Sacco societies, $\alpha=$ Autonomous factor, $\mathrm{X}_{1}=$ Leadership style,

$\mathrm{X}_{2}=$ Government regulations, $\beta$ s represents the beta coefficients of the independent variables,

$\mathrm{e}=$ Error term

Table 7.2: Regression Model Summary

\begin{tabular}{llllccc}
\hline Model Summary & R & R Square & $\begin{array}{l}\text { Adjusted } \\
\text { Square }\end{array}$ & R & $\begin{array}{l}\text { Std. Error of the } \\
\text { Estimate }\end{array}$ \\
\hline Model & 0.887401 & 0.787481 & 0.754786 & 0.8143 \\
\hline
\end{tabular}

Source: Author (2018)

Predictors: (Constant), leadership style, government regulation.

The goodness of fit shown by the regression summary model in table 7.2 had a value of 0.7874 shown by $\mathrm{R}^{2}$ which is coefficient of determination. It can therefore be deduced that leadership style and government regulation contribute 78.74 percent of the variations of sustainability of Sacco societies. Other factors that are not considered in the study contribute approximately $21.26 \%$ of the sustainability of Sacco societies.

The study further conducted ANOVA to test significance. ANOVA comprises of the computations that give rise to information pertaining levels of variance within particular regression models and hence forms a basis for the testing of significance. The significance level as shown in table 7.3 was $0.0 \%$ indicating that the data was good in reaching a conclusion since the p-value was less than $0.05 \%$. In comparing the critical value and the $\mathrm{F}$ value, it was concluded that the F value was greater hence the model is statistically significant. The F value at 5\% level of significance was 3.546. Since F value is far much greater than the F critical value (2.60), this satisfies that the overall model was statistically significant and thus we reject the null hypothesis. 
Table 7.3: Summary of ANOVA ${ }^{\mathrm{a}}$

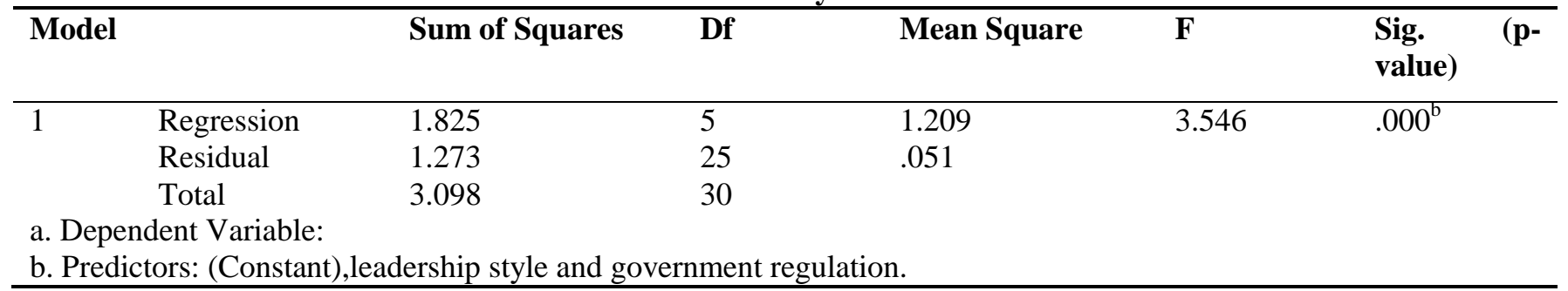

Source: Author (2018)

The equation obtained after running regression analysis in SPSS was

$\mathrm{Y}=1.851+0.587 \mathrm{X}_{1}+0.701 \mathrm{X}_{2}+\mathrm{e}$

Table 7.4: Summary of Coefficients of Regression Model

\begin{tabular}{|l|l|l|l|l|l|}
\hline & $\begin{array}{l}\text { Unstandardized } \\
\text { Coefficients }\end{array}$ & & $\begin{array}{l}\text { Standardized } \\
\text { Coefficients }\end{array}$ & T-values & $\begin{array}{l}\text { Sig. } \\
\text { value) }\end{array}$ \\
\hline & Beta & $\begin{array}{l}\text { Std. } \\
\text { Error }\end{array}$ & Beta & & \\
\hline (Constant) & 1.851 & .620 & & 0.912 & .000 \\
\hline Leadership style $\left(\mathrm{X}_{1}\right)$ & .587 & .127 & .787 & 2.275 & .025 \\
\hline Government regulations $\left(\mathrm{X}_{2}\right)$ & .701 & .336 & .97 & 2.322 & .036 \\
\hline
\end{tabular}

Source: Author (2018)

The regression equation shows that taking all factors (leadership style and government regulation) constant at zero, sustainability of Sacco societies will be 1.851 at $95 \%$ confidence. Holding all other predictor variables constant at zero, a unit increase in leadership style will increase sustainability by 0.587 and a unit increase in government regulations will increase sustainability by 0.701 . The Beta coefficients show the extent to which each variable contributes to the model. The larger the value means the larger the effect of predictor variable on dependent variable. The $\mathrm{T}$ and $\mathrm{p}$ values indicate the effect of predictor variable on criterion variable. From the results shown, all the calculated $\mathrm{T}$ values of the independent variables are greater than the critical value (1.708) thus we reject the null hypothesis. P-values as shown in table 4 were greater than 0.05 affirming the statistical significance of the model.

\section{Conclusions}

After thorough analysis of the findings, it emerged that leadership style is a driver to any Sacco to succeed. It helps in achieving the desired objectives through leaders trust and better leadership skills. Only Sacco's with better and compatible leadership style and prepared to change will survive in the market. It is upon the Sacco to ensure that issues concerning leadership are taken into consideration.

Government Policy can influence the sustainability of Sacco's. A regulation is a guide line to achieving a stated goal. The research made conclusions that organizations need to conform to the regulations set by the Government for sustainable growth. Failure to conformance can lead to Saccos not realizing profits. The government should also enact policies which encourage better competition and financial service provision to these institutions.

\section{Recommendations}

The study recommends that a Sacco should ensure that it adopts the best leadership style such that it should give better investment decisions for the Sacco and its members concerned to achieve sustainability and profitability. Through that Harambee Sacco will be able to have the best idea forward. The study recommends that any Sacco society should ensure that there is extensive research on how to conform to government regulations. The government should help in maintaining and keeping the going concern of any Sacco institutions toward its stated objectives of sustainability.

\section{Suggestions for Further Studies}

The research study was not able to cover all aspects of the factors affecting sustainability of Saccosocieties, therefore, more study should be done on other variables like product diversification, promotion. Loan's Interest, shares dividends and their influence on sustainability of Sacco societies. In addition, further research should be done on determinants of financial performance of Sacco societies in Kenya. 


\section{References}

Chijoriga, M. M. (2007). Application of Credit Scoring and Financialdistress reduction models to Commercial Banks Lending: The Case of Tanzania. Ph.DDissertation, WirtsChaftsnnversitat Wien (WU), Vienna.

Cooper, D. \& Schindler, P. (2003). Business Research Methods (8th edn) McGraw-Hill:New York.

Dawson, C. (2009). Introduction to Research Methods: A practical guide for anyone

Dawson, J. F. (2013). Moderation in management research: What, why, when and how. Journal of Business and Psychology, 29(1), 1-19.

DiMaggio,P.J.\&Powell,W.W.(1983).TheIronCageRevisited:Institutional Isomorphism and Collective Rationality in Organizational Fields. American Sociological Review, 48 (2),147-160.

Doug, M. and Scott, W.R. (2004). Organizations and Movements. In Social Movements and Organization Theory, Gerald Davis,

Gunga, S. (2009).Cooperative movement in Kenya and its potential for enhancement ofICT livelihoods. Unpublished master's thesis, Nairobi: University of Nairobi

GoK (2011). Report of the Ministry of Cooperatives in Sacco Movement in Kenya. Nairobi: Government Printers

GoK (2011). The Sacco Societies Act. Nairobi: Government Printers.

Kenya Gazette, SACCO Societies Act no. 14 (2008), Government Printer.

Republic of Kenya (2008).Economic Survey 2008, Nairobi, Central Bureau of Statistics, Ministry of Planning and National Development.

Kimando, L.N, Kihoro,J.M and Njogu, G.W(2012).Factors influencing the sustainability of Micro-Finance institutions in Murang'a Municipality.The Co-operative University of Kenya.

Kirkpatrick, C. (2001). 'Regulatory impact assessment in developing countries': research issues. Working Paper No. 5. Centre on Regulation and Competition, IDPM, University of Manchester.

KUSCCO, (2000). SACCO star No. 27. Nairobi

KUSCCO, (2003). SACCO star No. 42. Nairobi

KUSCCO, (2009). SACCO star No. 54. Nairobi

Kurian P.A(2011). What might it take to achieve sustainable development? Three contrasting sets of perspectives. What might it take to achieve sustainable development? Three contrasting sets of perspectives. Asia Pacific Journal of Public Administration. Vol 39, 2017,issue 3

Lari, L. R., (2009). The Power of Financial Ratios in Detecting Fraudulent Financial Reporting. The Case of SACCOS in Kenya. Unpublished Thesis. Strathmore University. Kenya

Ministry of Co-operative Development and Marketing, (2008) Co-operative Development Policy, Nairobi, Ministry of Co-operative Development and Marketing.

Meyer, J.W., and Rowan, B. (1991). Institutionalized Organizations: Formal Structuresas Myth and Ceremony. American Journal of Sociology, Vol. 83(2), 340 -363.

Mugenda, O. \&Mugenda, A. (2003). Research Methods: Quantitative \& QualitativeApproaches. Nairobi: Acts Press.

Mutua J.(2009). Strategic responses by Harambee Sacco to the changing operating environment. Unpublished MBA thesis, University of Nairobi.

Oliver, R.L. (2009), Whence Consumer loyalty?,Journal of Marketing, Vol. 63 pp.33-44.

Omisore, I., Munirat, Y. \&Nwufo, C. (2012). The modern portfolio theory as an investment decision tool. Journal of Accounting and Taxation Vol. 4(2), 19-28

SASRA. (2014). Regulatory Reporting Forms. Retrieved from http://www.sasra.go.ke/index.php/resources/regulatoryreporting-forms.

SASRA (2011). SACCO annual supervision report, 2010. Available from www.sasra.go.ke accessed on $4^{\text {th }}$ January 2019

Sarma, Gopal Kumar (2011). Is Microfinance Outreach Sustainable? A Case of Microfinance Institution Model in India (Paper prepared for "Second European Research Conference on Microfinance" held on June 16-June 18, 2011: University of Groningen, The Netherlands)

Smith,E. (2014). The impact of corporate social responsibility factors on the competitiveness of small and mediumsized enterprises.South African Journal of Economic and Management Sciences, Vol 17, No 2

UN (2009). World Economic Situation and Prospects 2009 (United Nations publication, Sales No. E.09.II.C.2), released in January 2009. 